\title{
Ameliorative Effect of Chelating Agents on Photosynthetic Attributes of Cd Stressed Sunflower
}

\author{
Rumana Sadiq ${ }^{1}$, Nazimah Maqbool${ }^{2}$, Muhammad Haseeb ${ }^{3}$ \\ ${ }^{1}$ Department of Botany, Government College Women University, Faisalabad, Pakistan \\ ${ }^{2}$ Department of Botany, University of Sargodha, Lyallpur Campus, Faisalabad, Pakistan \\ ${ }^{3}$ Department of Agronomy, University of Agriculture, Faisalabad, Pakistan \\ Email: nazimahmaqbool@gmail.com
}

How to cite this paper: Sadiq, R., Maqbool, N. and Haseeb, M. (2017) Ameliorative Effect of Chelating Agents on Photosynthetic Attributes of Cd Stressed Sunflower. Agricultural Sciences, 8, 149-160. https://doi.org/10.4236/as.2017.82010

Received: January 10, 2017

Accepted: February 1, 2017

Published: February 4, 2017

Copyright @ 2017 by authors and Scientific Research Publishing Inc. This work is licensed under the Creative Commons Attribution International License (CC BY 4.0).

http://creativecommons.org/licenses/by/4.0/ (c) (i) Open Access

\begin{abstract}
Excessive input of heavy metals in water reservoir and cultivated land primarily affects the growth and yield of crops. The aim of this work was to study the mechanism of Cd toxicity and damage to photosynthetic pigments and their efficiency and the potential of natural (OA) and synthetic chelators (EDTA) in assisting the phytoextractor sunflower plant. The pot experiment was laid out in a complete randomized way for $\mathrm{Cd}$, chelators and hybrids at seedling, vegetative and reproductive stages with three replications. Cd affects the gas exchange parameters directly or indirectly by affecting the light and dark reactions, while indirect effect includes inhibition of chlorophyll and carotenoids biosynthesis and degradation and alteration in $\mathrm{Chl} \mathrm{a} / \mathrm{b}$ ratio. Among two chelators, natural chelator $\mathrm{OA}$ found to be very supportive in ameliorating the $\mathrm{Cd}$ tocixity by phytoextractor in assistance to sunflower hybrid Hysun-33.
\end{abstract}

\section{Keywords}

Sunflower, Organic Chelate, Photosynthesis, Metal Toxicity

\section{Introduction}

Environmental pollution has become a serious problem at global level due to human activities [1] [2]. Urbanization and industrialization are proving hazardous to environment due to greater production of industrial wastes especially metallic elements [3] [4] [5].

Among metals, cadmium (Cd) is the most toxic pollutant of water, soil and atmosphere [6]. Naturally it occurs in soil due to weathering of sedimentary parent rocks [7]. It exists in the form of sulphides, oxides, and carbonates in 
lead, zinc and copper ores [8]. The industrial sources include phosphate fertilizers, nickel-cadmium batteries, pigments, plastics, ceramics and solar cells. The major culprits are phosphate fertilizers, Cd containing municipal waste and sewage sludge [9] [10] [11]. Other sources include burning of fossil fuels, mine tailings, waste and slag of smelter and urban refuse [8].

The irrigation of agricultural land with $\mathrm{Cd}$ containing waste water reduced the concentration of photosynthetic pigments such as chlorophyll a, chlorophyll b, total chlorophyll and carotenoids [12] [13] [14]. Exposure of plants to Cd causes leaf chlorosis which is most simple and visual indicator of toxicity of Cd [15] as it disrupts the structure and function of chloroplast by inhibiting the functioning of chlorophyll biosynthesizing enzymes [16] [17].

The higher Cd concentrations decreased the photosynthetic activity [18] by reducing chlorophyll synthesis, by reacting with porphobilinogen deaminase and d-ALA dehydratase - $\mathrm{SH}$ group, resulting in prophyrins and ALA (the intermediates of cholorophyll biosynthesis) [19] [20] and by producing chlorophyllide through protochlorophillide photoreduction [21].

Chelating agents either synthetic (EDTA, DTPA, HEDTA) or natural (oxalic acid, citric acid, acetic acid) are commonly used as amendments to induced phytoextraction [22]. EDTA is the most extensively used synthetic chelator for induced phytoextraction which dissolves the bonds between the metal and soil particles and promotes metal solubility and bioavailability for easy uptake by plants [23] [24]. Although the practice of using synthetic chelators such as EDTA, DTPA is very effective for phytoextraction of metals but their persistence in soil and low rate of degradation increases the risk of metals leaching and contamination of ground water [24] [25].

Oxalic acid is a cheap environment friendly and quickly biodegradable natural chelator that can be used in phytoextraction without having a danger of metal leaching and contamination of ground water [26] [27]. Its efficient role in Cd mobilization, translocation and phytoextraction has been extensively observed [28] [29].

This research was planned for comparative study of ameliorative potential of natural and synthetic chelators on photosynthetic attributes of two Cd treated sunflower hybrids.

\section{Material and Methods}

A pot experiment was performed in Old Botanical Garden, University of Agriculture, Faisalabad, Pakistan. The prevailing climatic conditions at the time of experiment were $34^{\circ} \mathrm{C}$ with $66 \%$ relative humidity in month of July 2015. Pots were filled with $10 \mathrm{~kg}$ soil and properly irrigated with water for maintaining suitable moisture content. Ten surface sterilized achenes (with $0.1 \%$ mercuric chloride) of two sunflower hybrids (Hysun-33 and FH-533) were sown at 1 inch depth in plastic pots. Treatments i.e. 0,250 and $450 \mathrm{mg} \cdot \mathrm{Cd} / \mathrm{kg}$ soil along with and without EDTA and OA @ $1 \mathrm{~g} / \mathrm{kg}$ soil each were applied in the rooting medium. Experiment was completely randomized with three factors factorial and 
three replications. After complete germination, four plants were kept for determination of chlorophyll and carotenoids pigments and gas exchange attributes. All the physiological and photosynthetic attributes were determined at seedling, vegetative and reproductive stages of plants.

Gas exchange parameters includes net assimilation rate $(A)$, transpiration rate $(E)$, sub-stomatal $\mathrm{CO}_{2}$ concentration $(C i)$, stomatal conductance $(g s)$ and water use efficiency $(A / E)$ were measured from a fully expanded youngest leaf by using an open system LCA-4 ADC portable infrared gas analyzer (Analytical Development Company, Hoddeson, England). The specifications/adjustments of IRGA were as follows: leaf surface area $11.35 \mathrm{~cm}^{3}$, ambient $\mathrm{CO}_{2}$ concentration (Cref) $342.12 \mu \mathrm{mol} / \mathrm{mol}$, temperature of leaf chamber (Tch) varied from $39.2^{\circ} \mathrm{C}$ to $43.9^{\circ} \mathrm{C}$, leaf chamber volume gas flow rate (v) $396 \mathrm{ml} / \mathrm{min}$, leaf chamber molar gas flow rate (U) $251 \mu \mathrm{mol} / \mathrm{sec}$, ambient pressure (P) $99.95 \mathrm{kPa}$, molar flow of air per unit leaf area (Us) $221.06 \mathrm{~mol} / \mathrm{m}^{2} / \mathrm{sec}$, PAR (Q leaf) at leaf surface was maximum up to $918 \mu \mathrm{mol} / \mathrm{m}^{2}$.

The concentration of chlorophyll ( $\mathrm{a}, \mathrm{b}$ and total) was calculated following the method of Arnon [30] and whereas carotenoids were calculated following the method of Davis [31]. Fresh leaves ( $0.2 \mathrm{~g})$ were grind well and extracted in $80 \%$ acetone at $4^{\circ} \mathrm{C}$. The extract was centrifuged at $10,000 \mathrm{rpm}$ for five minutes at $4^{\circ} \mathrm{C}$. The optical density of the supernatant was measured at 663,645 and 480 $\mathrm{nm}$ on spectrophotometer (Hitachi-220 Japan).

\section{Results}

\subsection{Photosynthetic Pigments}

The chlorophylls concentration (chl-a, chl-b, Total) significantly $(\mathrm{P}<0.01)$ reduced in the presence of $\mathrm{Cd}$ in growth medium in both hybrids. Hybrids varied significantly at all three growth stages. FH-533 showed maximum reduction of $92 \%$ in chlorophyll-a contents (chl-a), $96 \%$ in chl-b, $80 \%$ in chl-T and $96 \%$ in carotenoids by application of $450 \mathrm{mg} \cdot \mathrm{Cd} / \mathrm{kg}$ at seedling stage while in Hysun-33 this reduction was $67 \%, 76 \%, 55 \%$ and $90 \%$ respectively as compared to control. EDTA alone significantly affected chlorophylls and carotenoids at reproductive stage and caused $12 \%, 21 \%, 13 \%$ and $14 \%$ reduction in chl-a, chl-b, chl-T and carotenoids content of Hysun-33 and and 14\%, 22\%, 20\% and 23\% of FH-533 respectively (Figure 1). The OA alone significantly reduced $6 \%, 10 \%, 8 \%$ and $23 \%$ chl-a, chl-b, chl-T and carotenoids in Hysun-33 and 16\%, 8\%, 8\% and 15\% in FH-533 only at seedling stage (Figure 1).

Cadmium addition@ 250 and $450 \mathrm{mg} / \mathrm{kg}$ in growth medium in the presence of $1 \mathrm{~g} \cdot \mathrm{EDTA} / \mathrm{kg}$ imposed more severe effects on photosynthetic pigments of FH-533 than Hysun-33 as compared to control treated plants at vegetative and reproductive stages (Figure 1). $\mathrm{Cd} \times \mathrm{OA}$ interaction was significant for seedlings of two hybrids. In the presence of $1 \mathrm{~g} \cdot \mathrm{OA} / \mathrm{kg}$ soil maximum reduction was observed in combination with $450 \mathrm{mg} \cdot \mathrm{Cd} / \mathrm{kg}$ soil which caused reduction in chlorophylls and carotenoids contents of Hysun-33 and FH-533 respectively (Figure $1)$. 

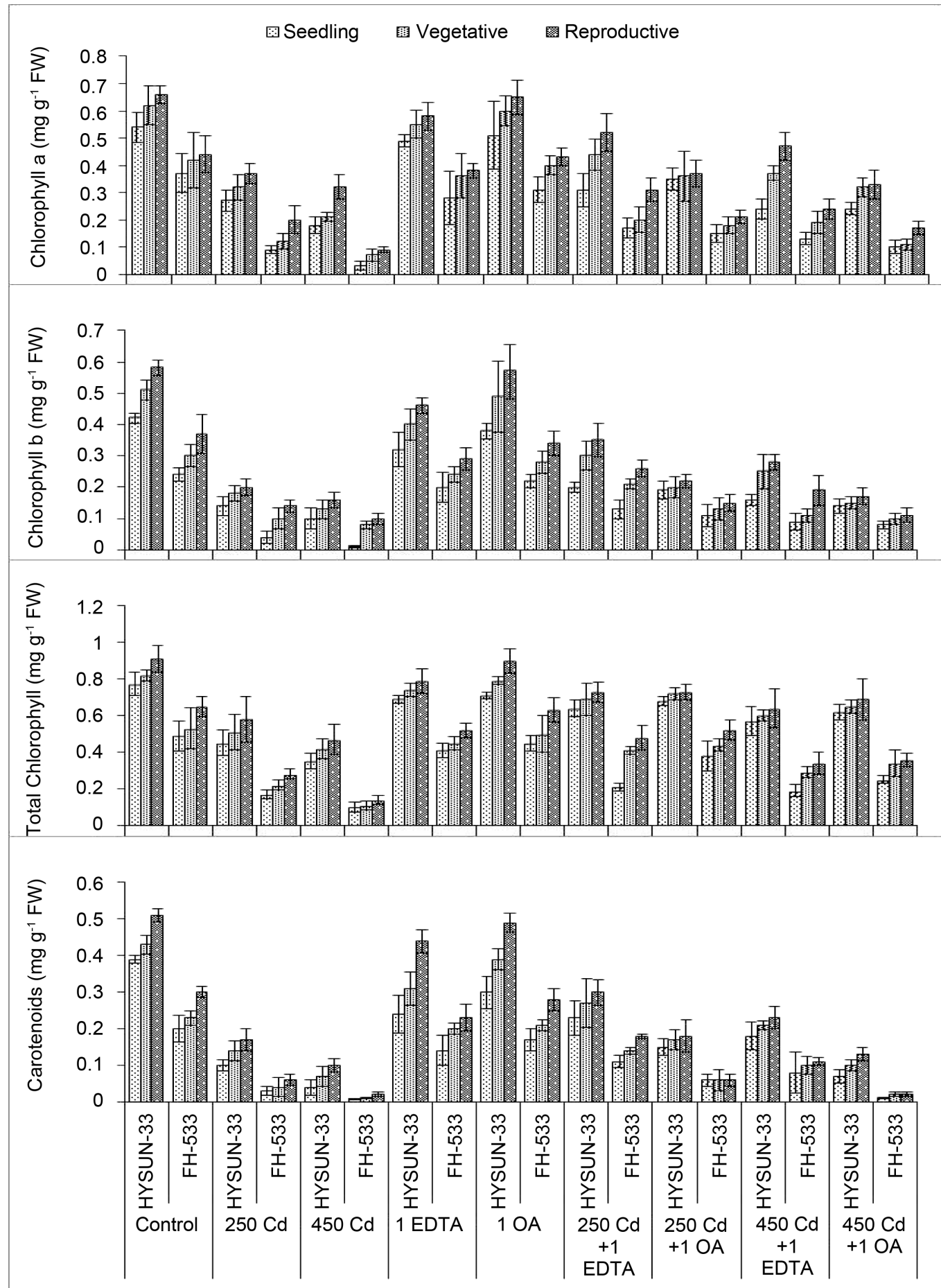

Figure 1. Effect of 250 and $450 \mathrm{mg} / \mathrm{kg}$ Cd along with EDTA $(1 \mathrm{~g} / \mathrm{kg})$ and OA $(1 \mathrm{~g} / \mathrm{kg})$ on pigments concentration of two sunflower hybrids (HYSUN-33 and FH-53) at seedling, vegetative and reproductive stages.

\subsection{Gas Exchange Attributes}

Statistical analysis revealed that cadmium significantly $(\mathrm{P}<0.01)$ affected the photosynthetic rate $(A)$, transpiration rate $(E)$, stomatal conductance $(g s)$ and sub-stomatal $\mathrm{CO}_{2}$ concentration $(C i)$ of treated plants at all three stages i.e. 
seedling, vegetative and reproductive stages. EDTA and OA alone had significant effects on gas exchange attributes only at seedling stage. Hybrids differed significantly throughout the studied period; Hysun-33 had better $A, E$, and $C i$ as compared to FH-533. Cadmium application @ 250 and $450 \mathrm{mg} \cdot \mathrm{Cd} / \mathrm{kg}$ resulted in decrease of gas exchange attributes at seedling stage and this reduction was greater at reproductive stage of both the hybrids. EDTA significantly reduced the physiological attributes at seedling stage in both the selected hybrids i.e., Hysun-33 and FH-533 but found significant at reproductive stage for $\mathrm{Ci}$ (Figure 2).

$\mathrm{Cd} \times$ EDTA interaction was also significant for these parameters at seedling stage, so the addition of EDTA @ $1 \mathrm{~g} / \mathrm{kg}$ in growth medium containing 250 and $450 \mathrm{mg} \cdot \mathrm{Cd} / \mathrm{kg}$ slightly affected them as compared to $\mathrm{Cd}$ alone (Figure 2). OA impact alone was statistically significant $(\mathrm{P}<0.01)$ at vegetative and reproductive stage of two hybrids for $C i$ and OA plus Cd interactive effect was proved significant for $A, E$ and $g s$ only at seedling stage. The impact of $\mathrm{OA}$ alone was mild as

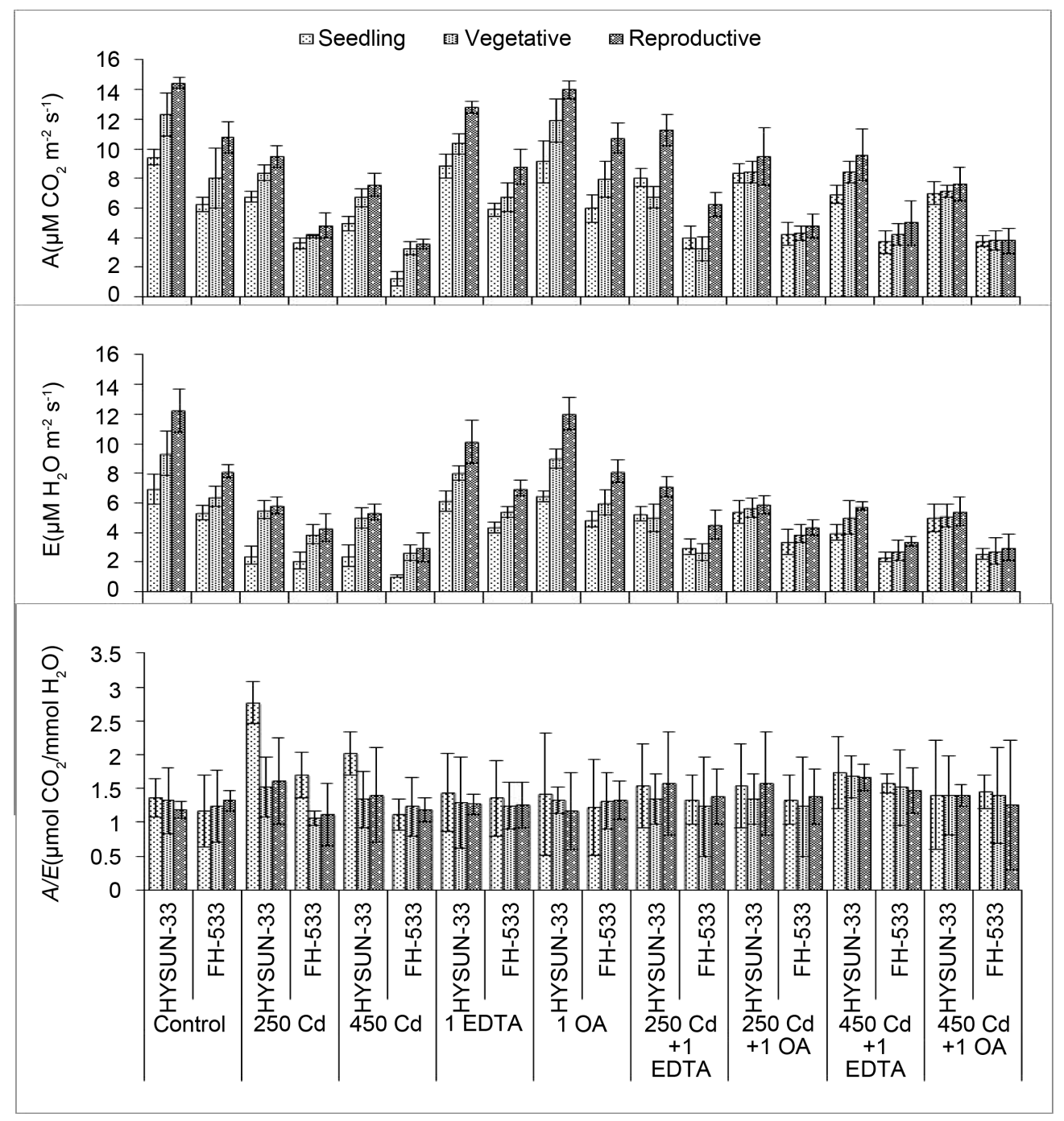

Figure 2. Effect of 250 and $450 \mathrm{mg} / \mathrm{kg}$ Cd along with EDTA $(1 \mathrm{~g} / \mathrm{kg})$ and OA $(1 \mathrm{~g} / \mathrm{kg})$ on net assimilation rate $(A)$, transpiration rate $(E)$ and water use efficiency $(A / E)$ of two sunflower hybrids (HYSUN-33 and FH-53) at seedling, vegetative and reproductive stages. 
compared to combined application with Cd and $1 \mathrm{~g} \cdot \mathrm{OA} / \mathrm{kg}+450 \mathrm{mg} \cdot \mathrm{Cd} / \mathrm{kg}$ affected the gas exchange attributes of two hybrids greater than $1 \mathrm{~g} \cdot \mathrm{OA} / \mathrm{kg}+250$ $\mathrm{mg} \cdot \mathrm{Cd} / \mathrm{kg}$ respectively (Figure 2 and Figure 3 ).

From analysis of variance it is clear that all the main factors i.e., $\mathrm{Cd}, \mathrm{OA}$ and EDTA proved non-significant alone and in combination for water use efficiency $(A / E)$ of sunflower hybrids throughout the studied. Only significant factor was hybrid at seedling stage. Minimum water use efficiency $1.11 \mu \mathrm{mol} \cdot \mathrm{CO}_{2} / \mathrm{mmol} \cdot \mathrm{H}_{2} \mathrm{O}$ was measured in $\mathrm{FH}-533$ under $250 \mathrm{mg} \cdot \mathrm{Cd} / \mathrm{kg}$ application at vegetative stage and maximum $3.19 \mu \mathrm{mol} \cdot \mathrm{CO}_{2} / \mathrm{mmol} \cdot \mathrm{H}_{2} \mathrm{O}$ was maintained by Hysun-33 under 250 $\mathrm{mg} \cdot \mathrm{Cd} / \mathrm{kg}$ application at seedling stage.

All the interactions for hybrids, $\mathrm{Cd}$ and chelating agents remained statistically non-significant $(\mathrm{P}>0.05)$ for pigments and gas exchange attributes at seedling, vegetative and reproductive stages.

\subsection{Discussion}

\section{a. Pigments}

Reduction in the concentration of photosynthetic pigments such as chl-a, chl-b, chl-T and accomplice pigments like carotenoids has been found a common symptom of metal toxicity in a number of species [12] [13] [14]. Decline in

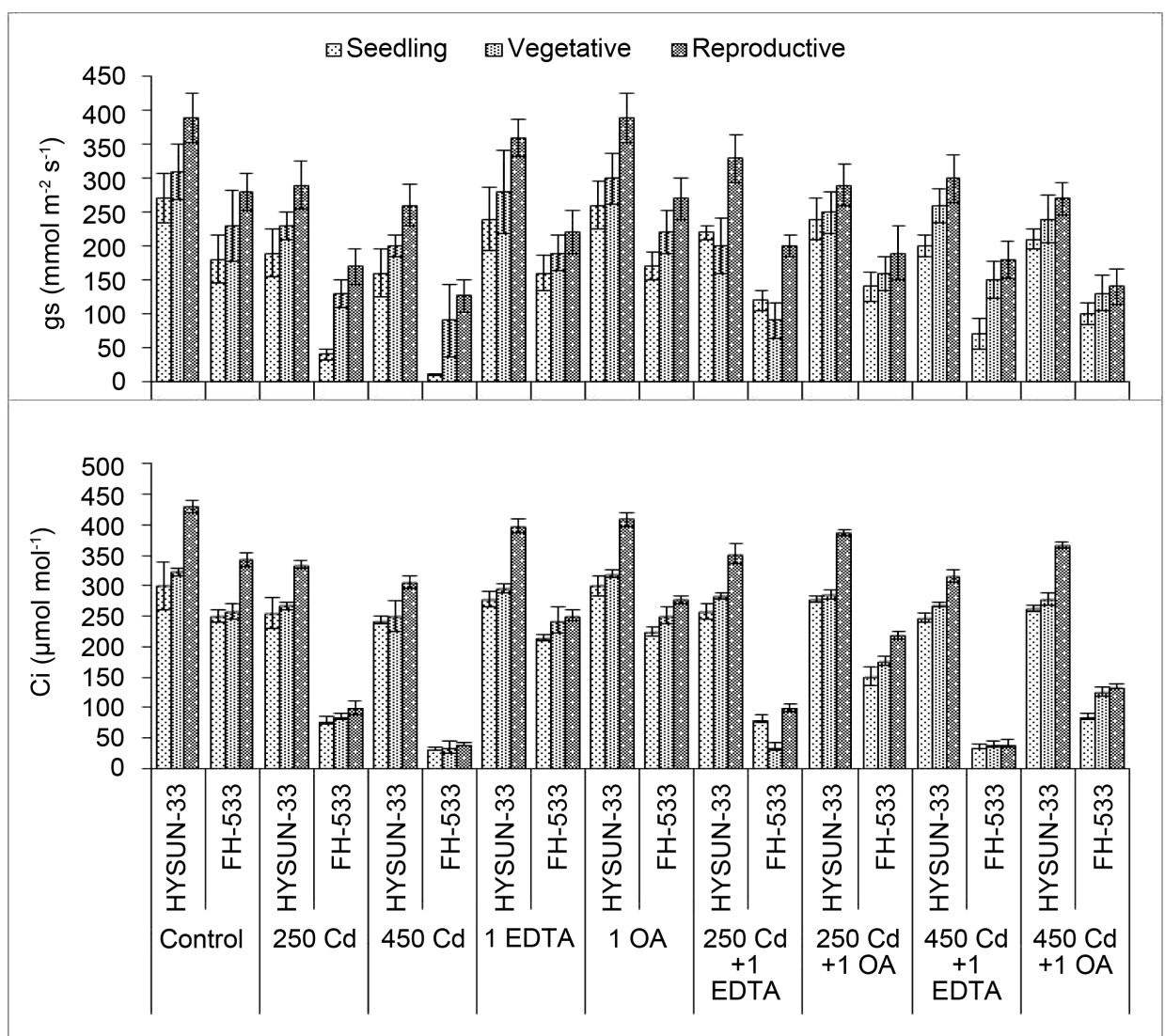

Figure 3. Effect of 250 and $450 \mathrm{mg} / \mathrm{kg}$ Cd along with EDTA $(1 \mathrm{~g} / \mathrm{kg})$ and OA $(1 \mathrm{~g} / \mathrm{kg})$ on sub-stomatal $\mathrm{CO}_{2}$ concentration $(C i)$ and stomatal conductance $(g s)$ of two sunflower hybrids (HYSUN-33 and FH-53) at seedling, vegetative and reproductive stages. 
photosynthetic pigments (Chlorophyll a, b and carotenoids) was noticed in sunflower under stress condition [30]. Exposure of plants to Cd causes leaf chlorosis which is most simple and visual indicator of Cd toxicity [15].

In present study Cd caused significant reduction in chl-a, chl-b, chl-T and accomplice pigment carotenoids especially at seedling stage as in pea plants [31] [32]. Cadmium reduced the chlorophyll concentration [33] [34] by removing the $\mathrm{Mg}$ ion from its binding position in chlorophyll [35] resulting in degradation of chlorophyll molecule [36] or by inhibiting the activities of enzymes involved in cholorophyll biosynthesis like protochlorophyllide reductase [37] porphobilinogen deaminase [38] aminolevulinic dehydratase [39] thus causing deficiency in $\mathrm{Fe}^{2+}$ and $\mathrm{Mg}^{2+}$ supply necessary for chlorophyll synthesis, and also causing inhibition of carbonic anhydrase activity due to $\mathrm{Zn}^{2+}$ scarcity [40].

Both chealtors i.e., EDTA and OA helped in reducing the damaging effects of Cd on pigments; however OA had given more assistance in ameliorating the damaging effects of Cd than EDTA. The sensitive hybrid FH-533 experienced more reduction in pigment contents than Hysun-33 (Figure 1). EDTA improved pigment status of Arundo donax L. grown in $\mathrm{Cd}, \mathrm{Pb}$ and arsenic contaminated soil [41] and Tribulus terrestris [42].

Chelators treated plants might be of increased concentration of $\mathrm{Fe}$ in the shoots which have influence on chlorophyll $b$ structure furthermore formation of metal-chelator complex which is incapable to penetrate the membranes of plant hence chelators decrease the metal mobility and then its toxicity [43].

Broadly, in interpretation of the high redox potential of $\mathrm{Cd}$ it is interpreted that during biosynthesis of photosynthetic pigments the reductive steps are inhibited due to Cd stress. In addition the activity of vital enzyme protochlorophyllide reductase, responsive for protochlorophyll reduction into chlorophyll known to be repressed [44].

\section{b. Gas exchange parameters}

In the present investigated study photosynthetic rate $(A)$, transpiration rates $(E)$, stomatal conductance $(g s)$ and substomatal $\mathrm{CO}_{2}$ concentration $(C I)$ were decreased and water use efficiency $(A / E)$ increased under the treatment of $\mathrm{Cd}$, EDTA and OA in combination or by their separate application in all harvest but this increasing and decreasing pattern in gas exchange parameters were more dominating at seedling stage. These trends are more pronounced when Cd was separately added in growth medium. According to present findings EDTA and OA application along with $\mathrm{Cd}$ helped in improving the gas exchange parameters of sunflower hybrids. The comparison between chelating agents showed that OA proved more helpful in reducing the adverse effects of $\mathrm{Cd}$ on gas exchange parameters than EDTA (Figure 2). EDTA influenced gas exchange parameter i.e., $A, E, g S, C i$ and $A / E$ of Tribulus terrestris growing in metal contaminated soil [42]. In present study the improved efficiency of gas exchange parameters by chelators (EDTA, OA) application might be due to formation of chelate with Cd which reduced the noxious effects of $\mathrm{Cd}$ [45]. Transpiration is a vital process for the enhancement of water soluble components or uptake of contaminants and 
flux to the upper plant parts [42]. The greater $A / E$ in $(\mathrm{Cd}+$ chelator) treated plants can be interpreted as plants effort to improve their water regime. Improved $A / E$ is largely a meaning of reduced water use then overall/net improvement in production of plant or biochemistry of assimilation [46].

Cd induced negative effects on $A, E$ and $C i$ in Brassica napus [47], Pea and barley [48], Maize [49]. Reduction in photosynthetic rate due to Cd toxicity might be the result of reduction in chlorophyll contents by its reaction with porphobilinogen deaminase and d-ALA dehydratase - $\mathrm{SH}$ group, resulting in prophyrins and ALA the intermediates of cholorophyll biosynthsis [19] [20] by producing chlorophyllide through protochlorophillide photoreduction [21]. In mitochondria and chloroplast for heme and chlorophyll synthesis ALA formation is the rate controlling and regulating step during tetrapyrrole biosynthetic pathway [50]. Cd restricts ALA synthesis reduce the chlorophyll synthesis and many other photosynthesis related reactions [16] [51] by causing Fe insufficiency [51]. The heme and chlorophyll biosynthesis is interrupted by Cd, as it reacts with the $-\mathrm{SH}$ functional groups like ALA dehydratase, ALA synthase, protochlorophyllide reductase and PBG deaminase [52].

Low Cd concentration increased transpiration rate of plants, however, decreased due to higher Cd concentrations. In Phragmites australis $50 \mu \mathrm{M} \mathrm{Cd}$ had no effect on this parameter, while reduction was noticed with $100 \mu \mathrm{M} \mathrm{Cd}$ treatments [53]. Higher Cd concentrations caused structural abnormalities in stomata resulting in rudimentary flawed stomata with reduced size and number, leading to depreciate stomatal conductance and modified rate of transpiration [54].

\section{Conclusion}

Cd affects the gas exchange parameters directly or indirectly by effecting the light and dark reactions. The direct effect of $\mathrm{Cd}$ on light reactions is on photosynthesis $\mathrm{O}_{2}$ evolution, photophosphorylation and reduction of NADP, while indirect effect includes inhibition of chlorophyll biosynthesis and degradation and alteration in Chl- $\mathrm{a}$ and $\mathrm{b}$ ratio.

\section{Acknowledgements}

This manuscript is the part of Ph.D. Thesis of Ms. Rumana Sadiq, University of Agriculture, Faisalabad, Pakistan and project was funded by Higher Education Commission of Pakistan under Indigenous Scholarship Program.

\section{References}

[1] Koptsik, S., Koptsik, G., Livantsova, S., Eruslankina, L., Zhmelkova, T. and Vologdina, Z.H. (2003) Heavy Metals in Soils near the Nickel Smelter: Chemistry, Spatial Variation, and Impacts on Plant Diversity. Journal of Environmental. Monitoring, 5, 441-450. https://doi.org/10.1039/b210397b

[2] Jarup, L. (2003) Hazards of Heavy Metal Contamination. British Medical Bulletin, 68, 167-182. https://doi.org/10.1093/bmb/ldg032

[3] Wei, B. and Yang, L. (2010) A Review of Heavy Metal Contaminations in Urban Soils, Urban Road Dusts and Agricultural Soils from China. Microchemical Journal, 
94, 99-107. https://doi.org/10.1016/j.microc.2009.09.014

[4] Yaylal1-Abanuz, G. (2011) Heavy Metal Contamination of Surface Soil around Gebze Industrial Area, Turkey. Microchemical Journal, 99, 82-92.

https://doi.org/10.1016/j.microc.2011.04.004

[5] Mireles, F., Davila, J.I., Pinedo, J.L., Reyes, E., Speakman, R.J. and Glascock, M.D. (2012) Assessing Urban Soil Pollution in the Cities of Zacatecas and Guadalupe, Mexico by Instrumental Neutron Activation Analysis. Microchemical Journal, 103, 158-164. https://doi.org/10.1016/j.microc.2012.02.009

[6] Ranieri, A., Castagna, A., Scebba, F., Careri, M., Zagnoni, I., Predieri, G., Pagliari, M. and Sanita di Toppi, L. (2005) Oxidative Stress and Phytochelatin Characterisation in Bread Wheat Exposed to Cadmium Stress. Plant Physiology and Biochemistry, 43, 45-54. https://doi.org/10.1016/j.plaphy.2004.12.004

[7] Alloway, B.J. (1995) Cadmium. In: Alloway, B.J., Ed., Heavy Metals in Soils, 2nd Edition, Blackie Academic \& Professional, London.

https://doi.org/10.1007/978-94-011-1344-1_6

[8] Anonymous (2010) UNEP Chemicals Branch, Final Review of Scientific Information on Cadmium (December 2010).

[9] EC. (2007) European Union Risk Assessment Report Cadmium Oxide and Cadmium Metal Part I-Environment, 1-635.

[10] Kabata-Pendias, A. and Mukherjee, A.B. (2007) Trace Elements from Soil to Human. Springer, Verlag, Berlin. https://doi.org/10.1007/978-3-540-32714-1

[11] ATSDR (2008) Draft Toxicological Profile for Cadmium. US Department of Health and Human Services, Agency for Toxic Substances and Disease Registry, Atlanta. http://www.atsdr.cdc.gov/toxprofiles/tp5-p.pdf

[12] Macfarlane, G.R. and Burchett, M.D. (2001) Photosynthetic Pigments and Peroxidase Activity as Indicators of Heavy Metals Stress in the Grey Mangrove Aviccenia marina (Forsk.) Vierh. Marine Pollution Bulletin, 42, 233-240. https://doi.org/10.1016/S0025-326X(00)00147-8

[13] Tantrey, S. and Agnihotri, R.K. (2010) Chlorophyll and Proline Content of Gram (Cicer arietinum L.) under Cadmium and Mercury Treatments. Research Journal of Agricultural Sciences, 1, 119-122.

[14] Pooja, V., Ram, A. and Gadi, B.R. (2012) Effect of Salicylic Acid on Photosynthetic Pigments and Some Biochemical Content in Vigna Seedlings under Cadmium Stress. Journal of Chemical Biological Physical Sciences, 2, 1801-1809.

[15] Hsu, Y.T. and Kao, C.H. (2003) Changes in Protein and Amino Acid Contents in Two Cultivars of Rice Seedlings with Different Apparent Tolerance to Cadmium. Plant Growth Regulation, 40, 147-155. https://doi.org/10.1023/A:1024248021314

[16] Siedlecka, A., Krupa, Z., Samuelsson, G., Oquist, G. and Gardestrom, P. (1997) Primary Carbon Metabolism in Phaseolus vulgaris Plants under Cd(II)/Fe Interaction. Plant Physiology and Biochemistry, 35, 951-957.

http://urn.kb.se/resolve?urn=urn:nbn:se:umu:diva-4463

[17] Pence, N.S., Larsen, P.B. and Ebbs, S.D. (2000) The Molecular Physiology of Heavy Metal Transport in the $\mathrm{Zn/Cd}$ Hyperaccumulator Thlaspi caerulescens. Proceedings of the National Academy of Sciences of the United States of America, 97, 49564960. https://doi.org/10.1073/pnas.97.9.4956

[18] Kovacs, S., Gaspar, L., Cseh, E., Kropfl, K. and Sarvari, E. (2005) Protective Effects of Phosphonomethyl-Sarcosine against the Copper and Cadmium Induced Inhibition of Leaf Development in Poplar. Acta Biologica Szegediensis, 49, 61-63. http://www.sci.u-szeged.hu/ABS 
[19] Padmaja, K., Prasad, D.D.K. and Prasad, A.R.K. (1990) Inhibition of Chlorophyll Synthesis in Phaseolus vulgaris L. Seedlings by Cadmium Acetate. Photosynthetica, 24, 399-405.

[20] Shakya, K., Chettri, M.K. and Sawidis, T. (2008) Impact of Heavy Metals (Copper, Zinc, and Lead) on the Chlorophyll Content of Some Mosses. Archives of Environmental Contamination and Toxicology, 54, 412-421. https://doi.org/10.1007/s00244-007-9060-y

[21] Stobart, A.K., Griffiths, W.T., Bukhari, I.A. and Sherwood, R.P. (1985) The Effect of $\mathrm{Cd}^{2+}$ on the Biosynthesis of Chlorophyll in Leaves of Barley. Physiologia Plantarum, 63, 293-298. https://doi.org/10.1111/j.1399-3054.1985.tb04268.x

[22] Nascimento, C.W.A., Amarasiriwardena, D. and Xing, B. (2006) Comparison of Natural Organic Acids and Synthetic Chelates at Enhancing Phytoextraction of Metals from a Multi-Metal Contaminated Soil. Environmental Pollution, 140, 114123. https://doi.org/10.1016/j.envpol.2005.06.017

[23] Jean, L., Bordas, F., Gautier-Moussard, C., Vernay, O., Hitmi, A. and Bollinger, J.C. (2008) Effect of Citric Acid and EDTA on Chromium and Nickel Uptake and Translocation by Datura innoxia. Environmental Pollution, 153, 555-563. https://doi.org/10.1016/j.envpol.2007.09.013

[24] Saifullah, E., Meers, M., Qadir, P., de Caritat, F.M.G., Tack, G.D., Du, L. and Zia, M.H. (2009) EDTA-Assisted Pb Phytoextraction. Chemosphere, 74, 1279-1291. https://doi.org/10.1016/j.chemosphere.2008.11.007

[25] Luo, C., Shen, Z. and Li, X. (2005) Enhanced Phytoextraction of Cu, Pb, Zn and Cd with EDTA and EDDS. Chemosphere, 59, 1-11. https://doi.org/10.1016/j.chemosphere.2004.09.100

[26] Wu, L.H., Luo, Y.M., Christie, P. and Wong, M.H. (2003) Effects of EDTA and Low Molecular Weight Organic Acids on Soil Solution Properties of a Heavy Metal Polluted Soil. Chemosphere, 50, 819-822. https://doi.org/10.1016/S0045-6535(02)00225-4

[27] Niu, Z., Sun, L. and Su, T. (2011) Relationships between Changes of Three Organic Acids (Oxalic Acid, Citric Acid and Tartaric Acid) and Phytoextration by Sunflower (Helianthus annuus L.) in Sand Cultures Contaminated with Cadmium and Lead. International Conference on Computer Distributed Control and Intelligent Environmental Monitoring, Changsha, 19-20 February 2011, 1646-1650.

[28] De Melo, E.E.C., do Nascimento, C.W.A., Accioly, A.M.A. and Santos, A.C.Q. (2008) Phytoextraction and Fractionation of Heavy Metals in Soil after Multiple Applications of Natural Chelants. Scientia Agricola, 65, 61-68.

[29] Oustan, S., Heidari, S., Neyshabouri, M.R., Reyhanitabar, A. and Bybordi, A. (2011) Removal of Heavy Metals from a Contaminated Calcareous Soil Using Oxalic and Acetic Acids as Chelating Agents. International Conference on Environment Science and Engineering, 8, 152-155.

[30] Haseeb, M. and Maqbool, N. (2015) Influence of Foliar Applied Nitrogen on Reproductive Growth of Sunflower (Helianthus annuus L.) under Water Stress. Agricultural Sciences, 6, 1413-1420. https://doi.org/10.4236/as.2015.612137

[31] Chen, X., Wang, J., Shi, Y., Zhao, M.Q. and Chi, G.Y. (2011) Effects of Cadmium on Growth and Photosynthetic Activities in Pakchoi and Mustard. Botanical Studies, 52, 41-46.

[32] Al-Hakimi, A.M.A. (2007) Modification of Cadmium Toxicity in Pea Seedlings by Kinetin. Plant Soil and Environment, 53, 129-135.

[33] Vijayaragavan, M., Prabhahar, C., Sureshkumar, J., Natarajan, A., Vijayaragavan, P. 
and Sharavanan, S. (2011) Toxic Effect of Cadmium on Seed Germination, Growth and Biochemical Contents of Cowpea (Vigna unguiculata L.) Plants. International Multidisciplinary Research Journal, 1, 1-6.

[34] Touiserkani, T. and Haddad, R. (2012) Cadmium-Induced Stress and Antioxidative Responses in Different Brassica napus Cultivars. Journal of Agriculture Science and Technology, 14, 929-937.

[35] Kupper, H., Kupper, F. and Spiller, M. (1996) Environmental Relevance of Heavy Metal Substituted Chlorophylls Using the Example of Water Plants. Journal of EXperimental Botany, 47, 259-266. https://doi.org/10.1093/jxb/47.2.259

[36] Otero, S., Nunez-Olivera, E., Martinez-Abaiqar, J., Tomas, R., Arroniz-Crespo, M. and Beaucourt, N. (2006) Effects of Cadmium and Enhanced UV Radiation on the Physiology and the Concentration of UV-Absorbing Compounds of the Aquatic Liverwort Jungermannia exsertifolia subsp. Cordifolia. Photochemical and Photobiological Sciences, 5, 760-769. https://doi.org/10.1039/B601105E

[37] Mysliwa-Kurdziel, B., Prasad, M.N.V. and Strzabka, K. (2004) Photosynthesis in Metal Stressed Plants. In: Prasad, M.N.V. Ed., Heavy Metal Stress in Plants. From Biomolecules to Ecosystems, 2nd Edition, Spinger-Verlag, Heidelberg and Narosa Publishing House, New Delhi, 146-181. https://doi.org/10.1007/978-3-662-07743-6_6

[38] Walley, J. (2005) The Effects of Low Level Cadmium Toxicity on Field and Greenhouse Grown Soybean (Glycine max). MSc. Thesis, Department of Botany, Miami University, Oxford.

[39] Noriega, G.O., Balestrase, K.B., Batlle, A. and Tomaro, M.L. (2007) Cadmium Induced Oxidative Stress in Soybean Plants Also by the Accumulation of Delta-Aminolevulinic Acid. Biometals, 20, 841-851. https://doi.org/10.1007/s10534-006-9077-0

[40] Van-Assche, F.V. and Clijsters, H. (1990) Effects of Metals on Enzyme Activity in Plants. Plant Cell and Environment, 13, 195-206. https://doi.org/10.1111/j.1365-3040.1990.tb01304.x

[41] Yang, M., Xiao, X.-Y., Miao, X.-F., Guo, Z.-H. and Wang, F.-Y. (2012) Effect of Amendments on Growth and Metal Uptake of Giant Reed (Arundo donax L.) Grown on Soil Contaminated by Arsenic, Cadmium and Lead. Transactions of Nonferrous Metals Society of China, 22, 1462-1469. https://doi.org/10.1016/S1003-6326(11)61342-3

[42] Geneva, M.M., Petrov, P., Boychinova, M., Lazarova, I., Todorov, I. and Stancheva, I. (2013) EDTA Reduces Heavy Metal Impacts on Tribulus terrestris Photosynthesis and Antioxidants. Russian Journal of Plant Physiology, 60, 623-632. https://doi.org/10.1134/S1021443713050117

[43] Ruley, A.T., Sharma, N.C., Sahi, S.V., Singh, S.R. and Sajwan, K.S. (2006) Effects of Lead and Chelators on Growth, Photosynthetic Activity and Pb Uptake in Sesbania drummondii Grown in Soil. Environmental Pollution, 44, 11-18. https://doi.org/10.1016/j.envpol.2006.01.016

[44] De Filippis, L.F. and Pallaghy, C.K. (1994) Heavy Metals: Sources and Biological Effects. In: Rai, L.C., Gaur, J.P. and Soeder, C.J. Eds., Advances in Limnology Series. Algae and Water Pollution, E. Scheizerbartsche Press, Stuttgart, 31-77.

[45] Chen, H. and Cutright, T. (2001) EDTA and HEDTA Effects on Cd, Cr, and Ni Uptake by Helianthus annuus. Chemosphere, 45, 21-28.

[46] Baszyfiski, T., Wajda, L., Krol, M., Wolinska, D., Krupa, Z. and Tukendorf, A. (1980) Photosynthetic Activities of Cadmium-Treated Tomato Plants. Physiologia Plantarum, 48, 365-370. https://doi.org/10.1111/j.1399-3054.1980.tb03269.x 
[47] Wan, G., Najeeb, U., Jilani, G., Naeem, M.S. and Zhou, W. (2011) Calcium Invigorates the Cadmium Stressed Brassica napus L. Plants by Strengthening Their Photosynthetic System. Environmental Science and Pollution Research, 18, 1478-1486. https://doi.org/10.1007/s11356-011-0509-1

[48] Januskaitiene, I. (2010) Impact of Low Concentration of Cadium on Photosynthesis and Growth of Pea and Barley. Environmental Research Engineering and Management, 3, 24-29.

[49] Krantev, A., Yordanova, R., Yand, T., Szalai, G. and Popova, L. (2008) Treatment with Salicylic Acid Decreases the Effect of Cadmium on Photosynthesis in Maize Plants. Journal of Plant Physiology, 165, 920-931. https://doi.org/10.1016/j.jplph.2006.11.014

[50] Porra, R.J. and Meisch, H.-U. (1984) The Biosynthesis of Chlorophyll. Trends in Biochemical Sciences, 9, 99-104. https://doi.org/10.1016/0968-0004(84)90104-X

[51] Jain, M., Pal, M., Gupta, P. and Gadre, R. (2007) Effect of Cadmium on Chlorophyll Biosynthesis and Enzymes of Nitrogen Assimilation in Greening Maize Leaf Segments: Role of 2-Oxoglutarate. Indian Journal of Experimental Biology, 45, 385389. https://www.ncbi.nlm.nih.gov/pubmed/17477312

[52] Mishra, S. and Dubey, R.S. (2005) Heavy Metal Toxicity Induced Alternations in Photosynthetic Metabolism in Plants. In: Pessarakli, M., Ed., 2nd Edition, Handbook of Photosynthesis, Taylor and Francis, Arizona, USA, 845-870.

[53] Pietrini, F., Iannelli, M.A., Pasqualini, S. and Massacci, A. (2003) Interaction of Cadmium with Glutathione and Photosynthesis in Developing Leaves and Chloroplasts of Phragmites australis (Cav.) Trin. Ex Steudel. Plant Physiology, 133, 829837. https://doi.org/10.1104/pp.103.026518

[54] Tran, T.A., Vassileva, V., Petrov, P. and Popova, L.P. (2013) Cadmium-Induced Structural Disturbances in Pisum sativum Leaves Are Alleviated by Nitric Acid. Turkish Journal of Botany, 37, 698-707.

Submit or recommend next manuscript to SCIRP and we will provide best service for you:

Accepting pre-submission inquiries through Email, Facebook, LinkedIn, Twitter, etc. A wide selection of journals (inclusive of 9 subjects, more than 200 journals)

Providing 24-hour high-quality service

User-friendly online submission system

Fair and swift peer-review system

Efficient typesetting and proofreading procedure

Display of the result of downloads and visits, as well as the number of cited articles

Maximum dissemination of your research work

Submit your manuscript at: http://papersubmission.scirp.org/

Orcontact as@scirp.org 